\title{
Analisis Laju Pembelajaran dalam Mengklasifikasi Data Wine Menggunakan Algoritma Backpropagation
}

\author{
Jaya Tata Hardinata1, Harly Okprana ${ }^{2}$, Agus Perdana Windarto ${ }^{3}$, Widodo Saputra4 \\ ${ }^{123}$ STIKOM Tunas Bangsa Pematangsiantar \\ ${ }^{4}$ AMIK Tunas Bangsa Pematangsiantar \\ Jl. Jend Sudirman Blok A No 1, 2 \& 3 Pematangsiantar \\ jayatatahardinata@stikomtb.ac.id¹, harly@amiktunasbangsa.ac.id ${ }^{2}$, \\ agus@amiktunasbangsa.ac.id³,widodo@amiktunasbangsa.ac.id ${ }^{4}$
}

\begin{abstract}
Backpropagation is an artificial neural network that has the architecture in conducting training and determining the right parameters to produce the correct output of similar but not the same input. One of the parameters that influences the determination of bacpropagation architecture is the rate of learning, where if the value of the learning rate is too high then the network architecture becomes unstable otherwise if the value of the learning rate is too low the network architecture converges and takes a long time in training network architecture. This research data is secondary data sourced from UCI Data Mechine Learning. The best network architecture in this study is 13-10-3, with different learning rates ranging from $0.01,0.03,0.06$, $0.01,0.13,0.16,0.2,0.23,0.026,0.3,0.35,0.4,0.45,0.5,0.55,0.6,0.65,0.7,0.75,0.8$, 0.9. From the 21 different learning rate values in the 13-10-3 network architecture, it is found that the level of learning rate is very important to get the right and fast network architecture. This can be seen in experiments with a learning rate of 0.65 can produce a better level of accuracy compared to a learning rate smaller than 0.65 .
\end{abstract}

Keywords: Learning Rate, ANN, Classification, Backpropagation, Wine

\begin{abstract}
Abstrak
Backpropagation merupakan jaringan syaraf tiruan yang memiliki arsitektur dalam melakukan pelatihan dan penentuan parameter yang tepat untuk menghasilkan keluaran yang benar terhadap masukan yang serupa tapi tidak sama. Salah satu parameter yang berpengaruh dalam penentuan arsitektur bacpropagation adalah laju pembelajaran, dimana jika nilai laju pembelajaran terlalu tinggi maka arsitektur jaringan menjadi tidak stabil sebaliknya jika nilai laju pembelajaran terlalu rendah arsitektur jaringan menjadi konvergen dan membutuhkan waktu yang lama dalam pelatihan arsitektur jaringan. Data penelitian ini merupakan data sekunder yang bersumber dari UCI Data Mechine Learning. Arsitektur jaringan terbaik pada penelitian ini adalah 13-10-3, dengan laju pembelajaran yang berbeda mulai dari $0.01,0.03,0.06,0.01,0.13,0.16,0.2,0.23,0.026,0.3,0.35,0.4,0.45,0.5,0.55,0.6$, $0.65,0.7,0.75,0.8,0.9$. Dari 21 nilai laju pembelajaran yang berbeda pada arsitektur jaringan 13-10-3 diperoleh bahwa tingkat laju pembelajaran sangat penting untukmendapatkan arsitektur jaringan yang tepat dan cepat. Hal ini terlihat pada percobaan dengan laju pembelajaran 0.65 dapat menghasilkan tingkat akurasi yang lebih baik dibandingkan dengan laju pembelajaran yang lebih kecil dari 0.65 .
\end{abstract}

Kata kunci: Laju Pembelajaran, JST, Klasifikasi, Backpropagation, Wine

\section{PENDAHULUAN}

Wine adalah minuman beralkohol yang merupakan hasil fermentasi anaerob (tanpa kehadiran 02) juice buah anggur, oleh khamir. Dalam proses 
fermentasi, ragi akan mengkonsumsi kandungan gula dari anggur dan mengubah menjadi etanol serta karbon dioksida. Jenis anggur yang berbeda dan ragi akan menghasilkan jenis wine yang berbeda. Variasi tersebut dapat dihasilkan dari interaksi kompleks antara perkembangan biokimia anggur, reaksi yang terlibat dalam proses fermentasi, lingkungan fermentasi (karakteristik khusus yang dihasilkan dari lingkungan geografis, geologi, iklim bahkan genetic tanaman anggur), appellation (penyebutan atau nama yang diberikan untuk memnerangkan di mana anggur untuk wine tersebut tumbuh), serta campur tangan manusia dalam proses keseluruhan.

Salah satu manfaat dari data mining adalah klasifikasi data, klasifikasi merupakan tahap penting dalam data mining. Klasifikasi bertujuan untuk memprediksi kelas dari suatu objek yang tidak di ketahui sebelumnya. Klasifiksi wine dapat di ukur secara obyektif dan subyektif, dimana subyektif dilakaukan oleh seorang pakar sedangkan obyektif dilakukan dengan cara uji laborotorium. Proses klasifikasi wine dapat membantu dalam menentukan kelas wine, sehingga dapat menggantikan pengukuran secara subyektif dalam penentuan kelas pada wine [1], [2]. Klasifiksi wine dapat di ukur secara obyektif dan subyektif, dimana subyektif dilakaukan oleh seorang pakar sedangkan obyektif dilakukan dengan cara uji laborotorium. Maka diperlukanya suatu jaringan syaraf tiruan untuk menentukan kelas wine dengan melakukan pengklasifikasian dengan jaringan saraf tiruan menggunakan algoritma backpropagation.

Dalam menentukan arsitektur algoritma backpropagation untuk mendapatkan hasil keluaran yang baik di pengaruhi dalam menentukan parameter -parameter yang tepat terhadapat arsitektur jaringan backpropagation. Pemilihan parameter sangat berpengaruh terhadap hasil keluaran pelatihan dan jumlah iterasi yang dilakukan jaringan backpropagation. Salah satu parameter pada jaringan saraf tiruan yang mempengaruhi jumlah iterasi pada jaringan backpropagation adalah laju pembelajaran, tingkat laju pembelajaran pada backpropagation sangatlah menentukan proses pembelajaran pada jaringan backpropagation dalam melakaukan klasifikasi. Tingkat laju pembelajaran dapat mengakibatkan jaringan menjadi konvergen jika terlalu kecil dan proses pembelajaran tidak stabil jika tingkat laju pembelajaran terlalu tinggi [3]. Sehingga laju pembelajaran penting dalam menentukan parameter yang tepat pada jaringan backpropagation dalam proses pembelajaran dan pengujian untuk menghasilkan tingkat akurasi yang baik dengan jumlah iterasi yang lebih baik dalam proses klasifikasi.

Proses klasifikasi wine dapat membantu dalam menentukan kelas wine, sehingga dapat menggantikan pengukuran secara subyektif dalam penentuan kelas pada wine. Penelitian yang berkaitan dengan klasifikasi wine dengan Metode K-Nearest Neighbor yang diterapkan pada penelitian ini menghasilkan akurasi maksimal sebesar $68,75 \%$ terjadi saat nilai $\mathrm{k}=16$, dan pada pengujian jumlah data, $80 \%$ atau 132 data sebagai data latih dan $20 \%$ atau 33 data sebagai data uji dari total 165 data, hasil akurasi maksimalnya 
66,48 \% [4], dan klasifikasi dengan BackPropagation Momentum Adaptive Learning Rate yang digabung dengan feature selection, dapat melakukan klasifikasi dengan tingkat akurasi mencapai 96\% [1]. Oleh karena itu penulis membuat penelitian untuk mengklasifikasi wine menggunakan Backpropagation, Salah satu metode/algoritma yang baik dalam proses pembelajaran dalam pengklasifikasian data sehingga dapat menggantikan penilaian subyektif dan obyektif dalam penentuan kelas wine

\section{METODOLOGI PENELITIAN}

\subsection{Jaringan Saraf Tiruan}

Jaringan Syaraf Tiruan merupakan salah satu representasi buatan dari otak manusia yang selalu mencoba untuk mensimulasikan proses pembelajaran pada otak manusia tersebut [5]-[7]. Istilah buatan disini digunakan karena jaringan syaraf ini diimplemintasikan dengan menggunakan program komputer yang mampu menyelesaikan sejumlah proses perhitungan selama proses pembelajaran. Model struktur jaringan saraf tiruan dapat dilihat pada gambar 1.

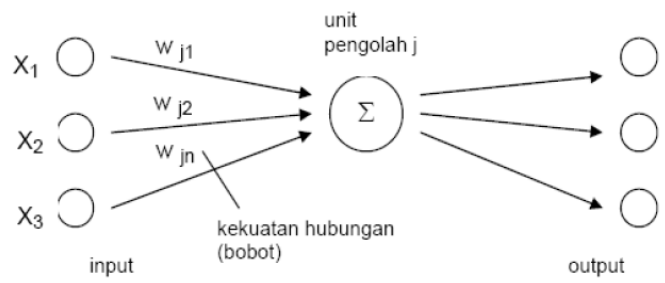

Gambar 1. Model Struktur Jaringan Saraf Tiruan

\subsection{Algoritma Backpropagation}

Propagasi balik atau back-propagation merupakan salah satu teknik pembelajaran/pelatihan supervised learning yang paling banyak digunakan. Metode ini merupakan salah satu metode yang sangat baik dalam menangani masalah pengenalan pola-pola kompleks. Di dalam jaringan propagasi balik, setiap unit yang berada di lapisan input terhubung dengan setiap unit yang ada di lapisan tersembunyi. Setiap unit yang ada di lapisan tersembunyi terhubung dengan setiap unit yang ada di lapisan output. Jaringan ini terdiri dari banyak lapisan (multilayer network). Ketika jaringan diberikan pola masukan sebagai pola pelatihan, maka pola tersebut menuju unit-unit lapisan tersembunyi untuk selanjutnya diteruskan pada unit-unit di lapisan keluaran [8]. Metode ini bekerja melalui proses secara iteratif dengan menggunakan sekumpulan contoh data (data training), membandingkan nilai prediksi dari jaringan dengan setiap contoh. Dalam setiap proses, bobot relasi dalam jaringan dimodifikasi untuk meminimalkan nilai Mean Square Error (MSE) antara nilai prediksi dari jaringan dengan nilai sesungguhnya. Modifikasi relasi ANN tersebut dilakukan dengan arah mundur, dari layer keluaran 
hingga layer pertama dari layer hidden sehingga metode ini disebut sebagai back propagation

\subsection{Model Arsitektur Backpropagation}

Backpropagation merupakan jaringan dengan lapisan jamak (multilayer network) yang memiliki ciri khas tertentu yaitu memiliki 3 jenis layer yakni layer input, layer tersembunyi, layer output. Backpropagation dapat menyelesaikan permasalahan yang kompleks dibandingkan dengan metode/algoritma yang lainnya [9]-[15].

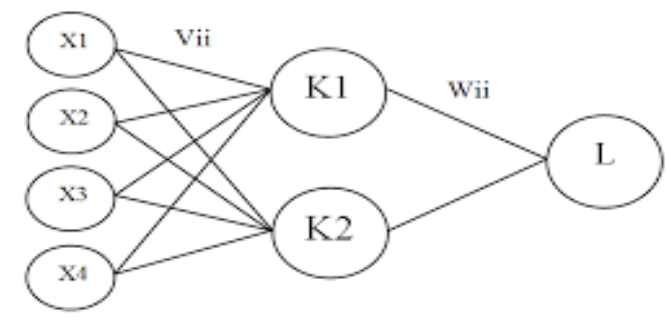

Gambar 2. Model Arsitektur Backpropagation

Keterangan :

Arsitektur jaringan yang digunakan dapat dilihat pada Gambar 2.4. yang terdiri dari tiga lapisan, yaitu : 4 lapis masukan (input), 2 lapis tersembunyi (hidden layer), dan 1 lapis keluaran (output). Dari gambar 2 dapat dijelaskan bahwa arsitektur backpopagation dengan $n$ buah masukkan $\left(\mathrm{x}_{1}, \mathrm{x}_{2}, \mathrm{x}_{3}, \ldots . . ., \mathrm{x}_{\mathrm{n}}\right)$ ditambah sebuah bias, sebuah lapisa tersembunyi yang terdiri dari $j$ unit tambahan sebuah bias, serta $k$ buah unit keluaran.

\subsubsection{Konsep Dasar Algoritma Backpropagation}

Setiap pola-pola informasi input dan output yang diberikan pada jaringan syaraf tiruan diproses dalam neuron. Neuron-neuron tersebut terkumpul didalam lapisan-lapisan yang disebut neuron layers. Lapisan-lapisan penyusun jaringan syaraf tiruan tersebut dapat dibagi menjadi tiga (3) [16][18], yaitu :

1. Lapisan input.

Unit-unit di dalam lapisan input disebut unit-unit input. Unit-unit input tersebut menerima pola inputan data dari luar yang menggambarkan suatu permasalahan.

2. Lapisan tersembunyi.

Unit-unit di dalam lapisan tersembunyi disebut unit-unit tersembunyi. Dimana outputnya tidak langsung dapat diamati.

3. Lapisan output.

Unit-unit di dalam lapisan output disebut unit-unit output. Output dari lapisan ini merupakan solusi jaringan syaraf tiruan terhadap suatu permasalahan. 


\subsection{Klasifikasi}

Klasifikasi adalah proses menemukan sekumpulan model/fungsi yang menjelaskan dan membedakan data kedalam kelas-kelas tertentu, dengan tujuan menggunakan model tersebut dalam menentukan kelas dari suatu objek yang belum diketahui kelasnya. Pada 2 proses dalam klasifikasi, yaitu [19]:

a. Proses learning/training Melakukan pembangunan model menggunakan data training. Pada penelitian ini menggunakan model JST.

b. Proses testing Melakukan tes terhadap data testing menggunakan model yang telah diperoleh dari proses training.

\section{HASIL DAN PEMBAHASAN}

\subsection{Data}

Dalam melakukan pelatihan dan pengujian, data yang digunakan diambil dari https://archive.ics.uci.edu/ml/datasets/wine, serta Target : 1 = Kelas 1 jumlah data sebanyak 59 data, $2=$ Kelas 2 jumlah data sebanyak 71 data dan 3 = Kelas 3 jumlah data sebanyak 48 data.

Tabel 1. Data Wine

\begin{tabular}{|c|c|c|c|c|c|c|c|c|c|c|c|c|c|c|}
\hline No & $\mathrm{X1}$ & $\mathrm{X} 2$ & $\mathrm{X3}$ & $\mathrm{X4}$ & $\mathrm{X5}$ & $\mathrm{X6}$ & $\mathrm{X7}$ & $\mathrm{X8}$ & $\times 9$ & X10 & X11 & X12 & $\mathrm{X} 13$ & $T$ \\
\hline 1 & 14,23 & 1,71 & 2,43 & 15,6 & 127 & 2,8 & 3,06 & 0,28 & 2,29 & 5,64 & 1,04 & 3,92 & 1065 & 1 \\
\hline 2 & 13,2 & 1,78 & 2,14 & 11,2 & 100 & 2,65 & 2,76 & 0,26 & 1,28 & 4,38 & 1,05 & 3,4 & 1050 & 1 \\
\hline 3 & 13,16 & 2,36 & 2,67 & 18,6 & 101 & 2,8 & 3,24 & 0,3 & 2,81 & 5,68 & 1,03 & 3,17 & 1185 & 1 \\
\hline 4 & 14,37 & 1,95 & 2,5 & 16,8 & 113 & 3,85 & 3,49 & 0,24 & 2,18 & 7,8 & 0,86 & 3,45 & 1480 & 1 \\
\hline 5 & 13,24 & 2,59 & 2,87 & 21 & 118 & 2,8 & 2,69 & 0,39 & 1,82 & 4,32 & 1,04 & 2,93 & 735 & 1 \\
\hline 6 & 14,2 & 1,76 & 2,45 & 15,2 & 112 & 3,27 & 3,39 & 0,34 & 1,97 & 6,75 & 1,05 & 2,85 & 1450 & 1 \\
\hline 7 & 14,39 & 1,87 & 2,45 & 14,6 & 96 & 2,5 & 2,52 & 0,3 & 1,98 & 5,25 & 1,02 & 3,58 & 1290 & 1 \\
\hline 8 & 14,06 & 2,15 & 2,61 & 17,6 & 121 & 2,6 & 2,51 & 0,31 & 1,25 & 5,05 & 1,06 & 3,58 & 1295 & 1 \\
\hline$\ldots$ & $\ldots$ & $\ldots$ & $\ldots$ & $\ldots$ & $\ldots$ & $\ldots$ & $\ldots$ & $\ldots$ & $\ldots$ & $\ldots$ & $\ldots$ & $\ldots$ & $\ldots$ & $\ldots$ \\
\hline 115 & 12,08 & 1,39 & 2,5 & 22,5 & 84 & 2,56 & 2,29 & 0,43 & 1,04 & 2,9 & 0,93 & 3,19 & 385 & 2 \\
\hline 116 & 11,03 & 1,51 & 2,2 & 21,5 & 85 & 2,46 & 2,17 & 0,52 & 2,01 & 1,9 & 1,71 & 2,87 & 407 & 2 \\
\hline 117 & 11,82 & 1,47 & 1,99 & 20,8 & 86 & 1,98 & 1,6 & 0,3 & 1,53 & 1,95 & 0,95 & 3,33 & 495 & 2 \\
\hline 118 & 12,42 & 1,61 & 2,19 & 22,5 & 108 & 2 & 2,09 & 0,34 & 1,61 & 2,06 & 1,06 & 2,96 & 345 & 2 \\
\hline 119 & 12,77 & 3,43 & 1,98 & 16 & 80 & 1,63 & 1,25 & 0,43 & 0,83 & 3,4 & 0,7 & 2,12 & 372 & 2 \\
\hline 120 & 12 & 3,43 & 2 & 19 & 87 & 2 & 1,64 & 0,37 & 1,87 & 1,28 & 0,93 & 3,05 & 564 & 2 \\
\hline 121 & 11,45 & 2,4 & 2,42 & 20 & 96 & 2,9 & 2,79 & 0,32 & 1,83 & 3,25 & 0,8 & 3,39 & 625 & 2 \\
\hline 122 & 11,56 & 2,05 & 3,23 & 28,5 & 119 & 3,18 & 5,08 & 0,47 & 1,87 & 6 & 0,93 & 3,69 & 465 & 2 \\
\hline 123 & 12,42 & 4,43 & 2,73 & 26,5 & 102 & 2,2 & 2,13 & 0,43 & 1,71 & 2,08 & 0,92 & 3,12 & 365 & 2 \\
\hline 124 & 13,05 & 5,8 & 2,13 & 21,5 & 86 & 2,62 & 2,65 & 0,3 & 2,01 & 2,6 & 0,73 & 3,1 & 380 & 2 \\
\hline 125 & 11,87 & 4,31 & 2,39 & 21 & 82 & 2,86 & 3,03 & 0,21 & 2,91 & 2,8 & 0,75 & 3,64 & 380 & 2 \\
\hline 126 & 12,07 & 2,16 & 2,17 & 21 & 85 & 2,6 & 2,65 & 0,37 & 1,35 & 2,76 & 0,86 & 3,28 & 378 & 2 \\
\hline 128 & 11,79 & 2,13 & 2,78 & 28,5 & 92 & 2,13 & 2,24 & 0,58 & 1,76 & 3 & 0,97 & 2,44 & 466 & 2 \\
\hline 129 & 12,37 & 1,63 & 2,3 & 24,5 & 88 & 2,22 & 2,45 & 0,4 & 1,9 & 2,12 & \begin{tabular}{|l|}
0,89 \\
\end{tabular} & 2,78 & 342 & 2 \\
\hline 130 & 12,04 & 4,3 & 2,38 & 22 & 80 & 2,1 & 1,75 & 0,42 & 1,35 & 2,6 & 0,79 & 2,57 & 580 & 2 \\
\hline 131 & 12,86 & 1,35 & 2,32 & 18 & 122 & 1,51 & 1,25 & 0,21 & 0,94 & 4,1 & 0,76 & 1,29 & 630 & 3 \\
\hline 132 & 12,88 & 2,99 & 2,4 & 20 & 104 & 1,3 & 1,22 & 0,24 & 0,83 & 5,4 & 0,74 & 1,42 & 530 & 3 \\
\hline$\ldots$ & $\ldots$ & $\ldots$ & $\ldots$ & $\ldots$ & $\ldots$ & $\ldots$ & $\ldots$ & $\ldots$ & $\ldots$ & $\ldots$ & $\ldots$ & $\ldots$ & $\ldots$ & $\ldots$ \\
\hline 156 & 13,17 & 5,19 & 2,32 & 22 & 93 & 1,74 & 0,63 & 0,61 & 1,55 & 7,9 & 0,6 & 1,48 & 725 & 3 \\
\hline 157 & 13,84 & 4,12 & 2,38 & 19,5 & 89 & 1,8 & 0,83 & 0,48 & 1,56 & 9,01 & 0,57 & 1,64 & 480 & 3 \\
\hline 158 & 12,45 & 3,03 & 2,64 & 27 & 97 & 1,9 & 0,58 & 0,63 & 1,14 & 7,5 & 0,67 & 1,73 & 880 & 3 \\
\hline
\end{tabular}


Jurnal Sains Komputer \& Informatika (J-SAKTI)

Volume 3 Nomor 2 September 2019, pp. 422-432

ISSN:2548-9771/EISSN:2549-7200

http://tunasbangsa.ac.id/ejurnal/index.php/jsakti

\begin{tabular}{|c|c|c|c|c|c|c|c|c|c|c|c|c|c|c|}
\hline No & $\mathbf{X 1}$ & $\mathbf{X 2}$ & $\mathbf{X 3}$ & $\mathbf{X 4}$ & $\mathbf{X 5}$ & $\mathbf{X 6}$ & $\mathbf{X 7}$ & $\mathbf{X 8}$ & $\mathbf{X 9}$ & $\mathbf{X 1 0}$ & $\mathbf{X 1 1}$ & $\mathbf{X 1 2}$ & $\mathbf{X 1 3}$ & $\mathbf{T}$ \\
\hline 159 & 14,34 & 1,68 & 2,7 & 25 & 98 & 2,8 & 1,31 & 0,53 & 2,7 & 13 & 0,57 & 1,96 & 660 & 3 \\
\hline 160 & 13,48 & 1,67 & 2,64 & 22,5 & 89 & 2,6 & 1,1 & 0,52 & 2,29 & 11,7 & 0,57 & 1,78 & 620 & 3 \\
\hline 161 & 12,36 & 3,83 & 2,38 & 21 & 88 & 2,3 & 0,92 & 0,5 & 1,04 & 7,65 & 0,56 & 1,58 & 520 & 3 \\
\hline 174 & 13,71 & 5,65 & 2,45 & 20,5 & 95 & 1,68 & 0,61 & 0,52 & 1,06 & 7,7 & 0,64 & 1,74 & 740 & 3 \\
\hline 175 & 13,4 & 3,91 & 2,48 & 23 & 102 & 1,8 & 0,75 & 0,43 & 1,41 & 7,3 & 0,7 & 1,56 & 750 & 3 \\
\hline 176 & 13,27 & 4,28 & 2,26 & 20 & 120 & 1,59 & 0,69 & 0,43 & 1,35 & 10,2 & 0,59 & 1,56 & 835 & 3 \\
\hline 177 & 13,17 & 2,59 & 2,37 & 20 & 120 & 1,65 & 0,68 & 0,53 & 1,46 & 9,3 & 0,6 & 1,62 & 840 & 3 \\
\hline 178 & 14,13 & 4,1 & 2,74 & 24,5 & 96 & 2,05 & 0,76 & 0,56 & 1,35 & 9,2 & 0,61 & 1,6 & 560 & 3 \\
\hline
\end{tabular}

\subsection{Analisis}

Setelah dilakukan normalisasi, maka akan dilakukan pelatihan menggunakan software Matlab R2011b. Adapun parameter-parameter yang diperlukan dalam proses pelatihan dan pengujian adalah sebagai berikut:

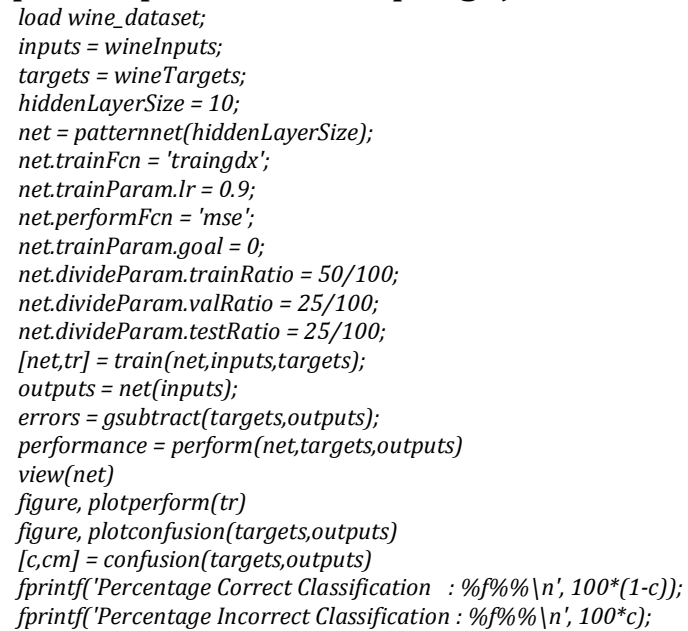

\subsection{Pelatihan dan Pengujian Data}

Pada penelitian ini menggunakan 1 (satu) arsitektur jaringan pelatihan dan pengujian 13-10-3 dengan laju pembelajaran yang berbeda dengan kombinasi laju pembelajaran sebagai berikut $0.01,0.03,0.06,0.01,0.13,0.16$, $0.2,0.23,0.026,0.3,0.35,0.4,0.45,0.5,0.55,0.6,0.65,0.7,0.75,0.8,0.9$. Berdasarkan model arsitektur 13-10-3 dapat dijabarkan bahwa 13 merupakan data neuron input layer, 10 merupakan data neuron hidden layer dan 3 merupakan data neuron output layer. Nialai Laju pembelajaran terbaik. Dapat dilihat pada tabel 2 . berikut.

Tabel 2. Hasil Pelatihan dan Pengujian data Wine

\begin{tabular}{|c|r|c|c|}
\hline \multirow{2}{*}{ No. } & \multirow{2}{*}{ Laju Pembelajaran } & \multicolumn{2}{|c|}{ Hasil } \\
\cline { 3 - 4 } & & Akurasi & Performance \\
\hline 1 & 0.01 & $98.8764040 \%$ & 0.01290 \\
\hline 2 & 0.03 & $98.8764040 \%$ & 0.01320 \\
\hline 3 & 0.06 & $98.8764040 \%$ & 0.01310 \\
\hline 4 & 0.1 & $98.8764040 \%$ & 0.01290 \\
\hline 5 & 0.13 & $98.3146070 \%$ & 0.01320 \\
\hline
\end{tabular}

Analisis Laju Pembelajaran Data Wine dengan Backpro (Jaya Tata Hardinata) |427 
Jurnal Sains Komputer \& Informatika (J-SAKTI)

Volume 3 Nomor 2 September 2019, pp. 422-432

ISSN:2548-9771/EISSN:2549-7200

http://tunasbangsa.ac.id/ejurnal/index.php/jsakti

\begin{tabular}{|c|r|c|c|}
\hline \multirow{2}{*}{ No. } & \multirow{2}{*}{ Laju Pembelajaran } & \multicolumn{2}{|c|}{ Hasil } \\
\cline { 3 - 4 } & & Akurasi & Performance \\
\hline 6 & 0.16 & $98.3146070 \%$ & 0.01310 \\
\hline 7 & 0.2 & $98.3146070 \%$ & 0.01290 \\
\hline 8 & 0.23 & $98.3146070 \%$ & 0.01300 \\
\hline 9 & 0.26 & $98.3146070 \%$ & 0.01280 \\
\hline 10 & 0.3 & $98.3146070 \%$ & 0.01280 \\
\hline 11 & 0.35 & $98.3146070 \%$ & 0.01280 \\
\hline 12 & 0.4 & $98.3146070 \%$ & 0.01300 \\
\hline 13 & 0.45 & $98.3146070 \%$ & 0.01280 \\
\hline 14 & 0.5 & $98.3146070 \%$ & 0.01280 \\
\hline 15 & 0.55 & $98.3146070 \%$ & 0.01280 \\
\hline 16 & 0.6 & $96.6292130 \%$ & 0.02490 \\
\hline 17 & 0.65 & $98.3146070 \%$ & 0.01270 \\
\hline 18 & 0.7 & $96.6292130 \%$ & 0.02550 \\
\hline 19 & 0.8 & $96.6292130 \%$ & 0.02470 \\
\hline 20 & 0.9 & $96.6292130 \%$ & 0.02410 \\
\hline 21 & 0.95 & $96.6292130 \%$ & 0.02370 \\
\hline
\end{tabular}

Berdasarkan tabel 2. dapat dilihat bahwa tingkat laju pembelajaran sangat berpengaruh terhadap arsitektur jaringan, dimana terjadi pada tingkat laju pembelajaran 0.65 dengan menghasilkan tingkat akurasi yakni sebesar 98,3\% dimana tinggakat akurasi ini lebih baik dari tingkat laju pembelajaran yang lebih kecil dari 0.65 yaitu 0.6. sehingga pada arsitektur jaringan ini dapat dilihat bahwa semangkin lebih tingggi tingkat lajur pembelajaran tidak akan membuat arsitektur jaringan semangkin tidak stabil dalam melakukan pembelajaran.

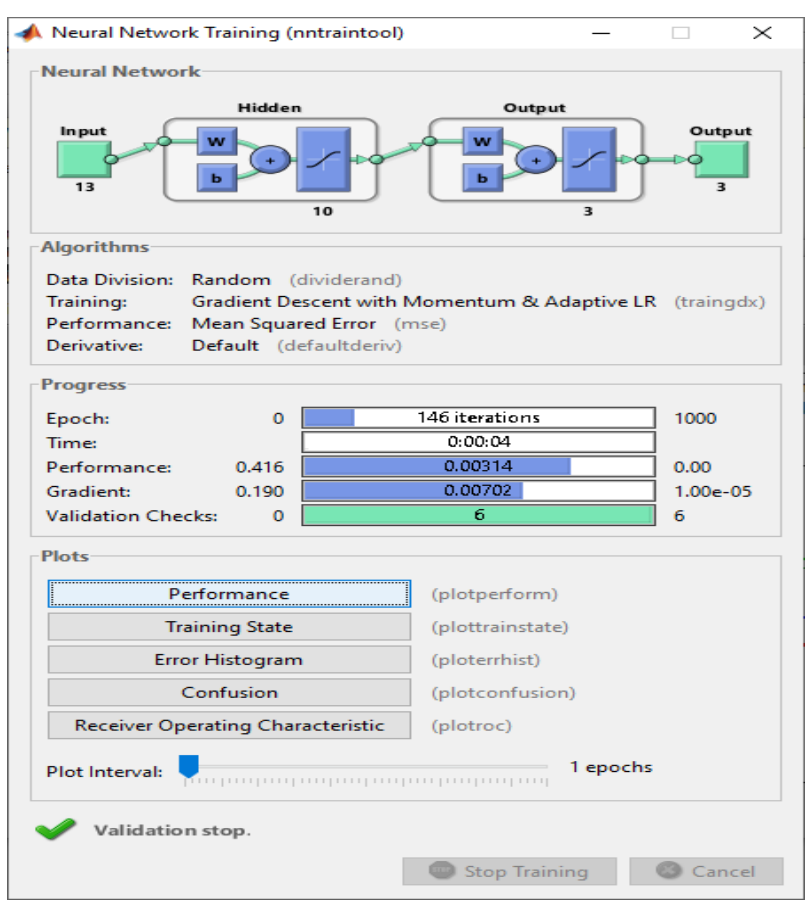

Gambar 3. Hasil Arsitektur Jaringan Dengan laju Pembelajaran 0.01 
Dari gambar 3 dapat dijelaskan bahwa Epoch yang terjadi sebesar 146 dengan lama waktu 4 detik, performa 0.00314. Divisi data acak, fungsi pelatihan yang di gunakan adalah Gradient Descent Momentum \& Adative LR (traingdx) dengan perporma Mean Squared Error dengan arsitektur 13-10-3.

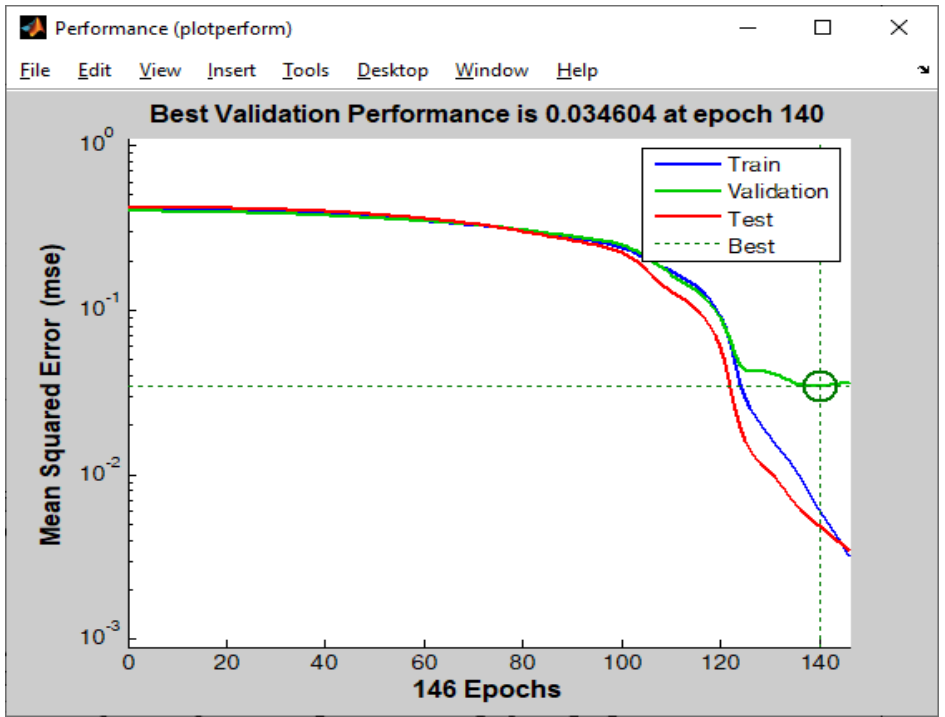

Gambar 4. Hasil Performance Mean Squared Error (MSE)

Dari gambar 4 dapat diperoleh Mean Square Error (MSE) sebesar 0,034604 pada Epoch 140. Dengan hasil garis perbandingan antara data pelatihan dan data uji yang mendekati hasil mean squared Error (Mse) yang sama.

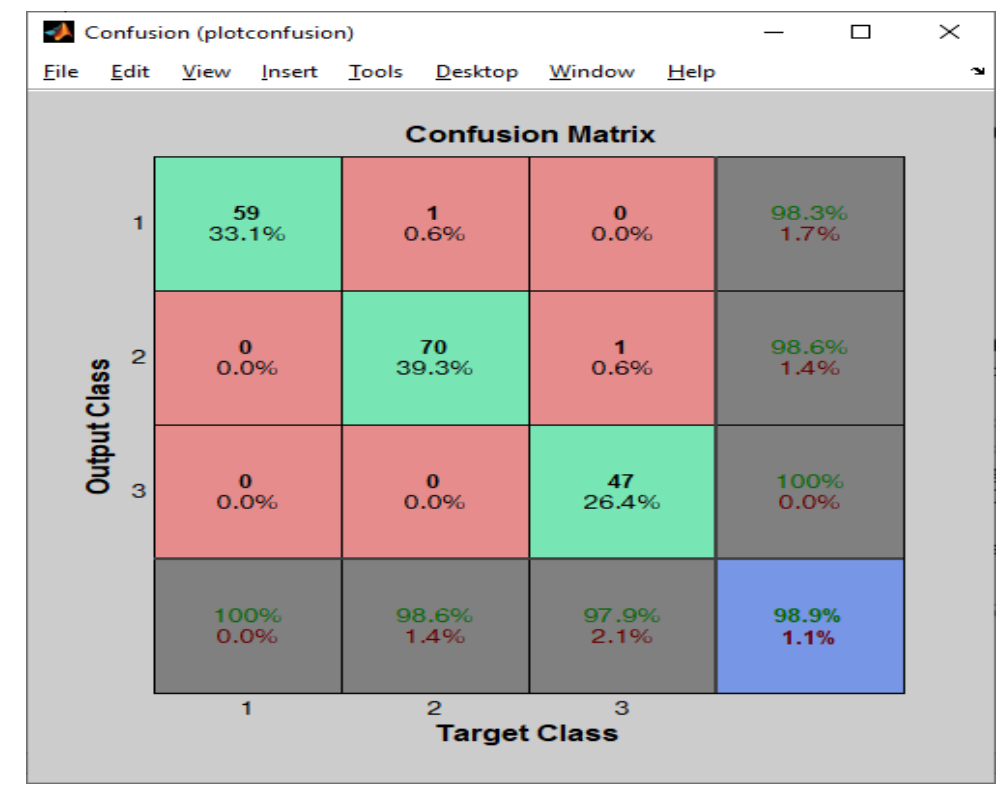

Gambar 5. Hasil Confusion

Dari gambar 5 dapat diperoleh Tinggakt Akurasi klasifikasi sebesar 98.9\% dengan kelasahan klasifikasi $1.1 \%$. pada kelas 1 terdapat 59 data dengan Analisis Laju Pembelajaran Data Wine dengan Backpro (Jaya Tata Hardinata) 1429 
kesalahan hasil klasifikasi $0 \%$, data kelas 2 dengan jumlah data 71 data dengan kesalahan hasil klasifikasi $0.6 \%$ serta data kelas 3 dengna jumlah data 48 data dengan kesalahan hasil klasifikasi $0.6 \%$.

Tabel 3. Hasil Klasifikasi Data Wine

\begin{tabular}{|c|c|c|c|c|c|c|c|c|c|c|c|c|c|c|c|}
\hline No & 1 & 2 & & & 55 & 6 & 7 & 8 & 9 & 10 & 11 & 12 & 13 & $T$ & \\
\hline & 3 & & & & & 2,8 & & & 29 & 4 & & & & & \\
\hline & & & & & & & & & & & & & & & \\
\hline 3 & 3,1 & & & & & 2,8 & & & & & & & & & \\
\hline 4 & 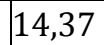 & & & & & 3,85 & & & & & & & & & \\
\hline 5 & 3,2 & & & & & 2,8 & & & & & & & & & \\
\hline & & & & & & 3 & & & & & & & & & \\
\hline 7 & 4,3 & & & & & 2,5 & & & 98 & & & & & & \\
\hline 8 & 4,06 & & & & & 2,6 & & & 25 & 55 & & & 1295 & & \\
\hline & & & & & & & & & & & & & & & \\
\hline 73 & 3,4 & & & & & 1,88 & & & 03 & & & & & & \\
\hline 74 & 2,9 & & & & & 3,3 & $2, \varepsilon$ & & 96 & & & & & & \\
\hline 75 & 1,9 & & & 2 & 10 & 3,38 & 2 , & & 55 & 1 & & & 36 & 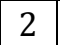 & \\
\hline 76 & ato & & & & & & & & & & & & & & \\
\hline & & & & & & & & & & & & & & & \\
\hline & 12,51 & 24 & - & 5 & 85 & 2 & & 6 & 25 & 45 & 75 & & 0 & 3 & \\
\hline & 12 & & & & & 1,62 & & & & & & & & & \\
\hline & 12,2 & 4 & & & 8 & & 0 , & & & 3, & & & & & \\
\hline & 13,4 & 4, & & & 112 & 1,98 & 0 & & 1 & & & & & & \\
\hline & 12,2 & 3,03 & & & 6 & 5 & & & 73 & & & & 0 & 3 & \\
\hline & 12,7 & 2,39 & & & 86 & 1,3 & 0, & & 64 & 9,89 & & & 0 & 3 & \\
\hline & 14, & & & & 91 & 1,6 & & & 4 & ]$^{2}$ & & & & 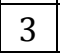 & \\
\hline & 13,7 & & & & 95 & 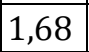 & & & 16 & 7 , & & & & & \\
\hline & 13,4 & & & & 102 & & & & 41 & & & & & 3 & 3 \\
\hline & 13, & & & & 1 & 1,5 & & & 35 & 10,2 & & & & 3 & \\
\hline & 13, & & & & 12 & & & & & & & & & 3 & \\
\hline 8 & & & & & נo & 5 & 4 & & 1,35 & $\mid 9,2$ & 0,61 & & 560 & 3 & \\
\hline
\end{tabular}

Berdasarkan tabel 3 dapat dilihat bahwa hasil klasifikasi data wine terjadi pada data dengan kelas wine 2 dan 3. Kesalahan tersebut terjadi pada data ke 74 yang mana kelas data wine 2 arsitektur jaringan menghasilkan kelas 1 dan data ke 135 dimana kelas data wine 3 arsitektur jaringan menghasilkan keluaran 2.

\section{SIMPULAN}

Kesimpulan yang dapat diambil dari penelitian ini antara lain :

1. Laju pembelajaran sangant berpengaruh dalam mendapatkan hasil yang tepat dan cepat. 
2. Semakin kecil tingkat laju pembelajaran pada penelitian klasifikasi data wine semakin tinggi tingkat akurasi dan semakin besar juga tinggak Epoch dalam proses pelatihan arsitektur jaringan.

3. Tingkat laju pembelajarn yang lebih tinggi belum tentu membuat arsitektur jaringan semangkin tidak stabil dalam penelitian klasifikasi data wine.

\section{DAFTAR PUSTAKA}

[1] W. Maharani, "Klasifikasi Data Menggunakan JST Backpropagation Momentum dengan Adaptive Learning Rate," in Seminar Nasional Informatika 2009 (semnasIF 2009), 2009, vol. 2009, pp. 25-31.

[2] D. A. Nasution, H. H. Khotimah, and N. Chamidah, "Perbandingan Normalisasi Data untuk Klasifikasi Wine Menggunakan Algoritma K-NN," Computer Engineering, Science and System Journal, vol. 4, no. 1, p. 78, 2019.

[3] A. Wanto et al., "Analysis of the Backpropagation Algorithm in Viewing Import Value Development Levels Based on Main Country of Origin," Journal of Physics: Conf. Series, vol. 1255, pp. 1-6, 2019.

[4] A. Arandika, "Implementasi Algoritma K-Nearest Neighbor (K-NN) Untuk Klasifikasi Data Wine," 2014.

[5] A. Wanto and A. P. Windarto, "Analisis Prediksi Indeks Harga Konsumen Berdasarkan Kelompok Kesehatan Dengan Menggunakan Metode Backpropagation," Jurnal \& Penelitian Teknik Informatika Sinkron, vol. 2, no. 2, pp. 37-44, 2017.

[6] A. Wanto, A. P. Windarto, D. Hartama, and I. Parlina, "Use of Binary Sigmoid Function And Linear Identity In Artificial Neural Networks For Forecasting Population Density," International Journal Of Information System \& Technology, vol. 1, no. 1, pp. 43-54, 2017.

[7] A. Wanto, M. Zarlis, Sawaluddin, and D. Hartama, "Analysis of Artificial Neural Network Backpropagation Using Conjugate Gradient Fletcher Reeves in the Predicting Process," Journal of Physics: Conference Series, vol. 930, no. 1, pp. 17, 2017.

[8] A. P. Windarto, M. R. Lubis, and Solikhun, "MODEL ARSITEKTUR NEURAL NETWORK DENGAN BACKPROPOGATION PADA PREDIKSI TOTAL LABA RUGI KOMPREHENSIF BANK UMUM KONVENSIONAL," Kumpulan jurnaL Ilmu Komputer (KLIK), vol. 5, no. 2, pp. 147-158, 2018.

[9] S. P. Siregar and A. Wanto, "Analysis of Artificial Neural Network Accuracy Using Backpropagation Algorithm In Predicting Process (Forecasting)," International Journal Of Information System \& Technology, vol. 1, no. 1, pp. 3442, 2017.

[10] J. R. Saragih, M. Billy, S. Saragih, and A. Wanto, "Analisis Algoritma Backpropagation Dalam Prediksi Nilai Ekspor (Juta USD)," Jurnal Pendidikan Teknologi dan Kejuruan, vol. 15, no. 2, pp. 254-264, 2018.

[11] E. Hartato, D. Sitorus, and A. Wanto, "Analisis Jaringan Saraf Tiruan Untuk Prediksi Luas Panen Biofarmaka di Indonesia," Jurnal semanTIK, vol. 4, no. 1, pp. 49-56, 2018.

[12] S. Setti and A. Wanto, "Analysis of Backpropagation Algorithm in Predicting the Most Number of Internet Users in the World," JOIN Ournal Online Informatika), vol. 3, no. 2, pp. 110-115, 2018. 
[13] R. E. Pranata, S. P. Sinaga, and A. Wanto, "Estimasi Wisatawan Mancanegara Yang Datang ke Sumatera Utara Menggunakan Jaringan Saraf," Jurnal semanTIK, vol. 4, no. 1, pp. 97-102, 2018.

[14] A. A. Fardhani, D. Insani, N. Simanjuntak, and A. Wanto, "Prediksi Harga Eceran Beras Di Pasar Tradisional Di 33 Kota Di Indonesia Menggunakan Algoritma Backpropagation," Jurnal Infomedia, vol. 3, no. 1, pp. 25-30, 2018.

[15] J. Wahyuni, Y. W. Paranthy, and A. Wanto, "Analisis Jaringan Saraf Dalam Estimasi Tingkat Pengangguran Terbuka Penduduk Sumatera Utara," Jurnal Infomedia, vol. 3, no. 1, pp. 18-24, 2018.

[16] Y. A. Lesnussa, S. Latuconsina, and E. R. Persulessy, "Aplikasi Jaringan Saraf Tiruan Backpropagation untuk Memprediksi Prestasi Siswa SMA ( Studi kasus: Prediksi Prestasi Siswa SMAN 4 Ambon )," Jurnal Matematika Integratif, vol. 11, no. 2, pp. 149-160, 2015.

[17] M. A. Razak and E. Riksakomara, "Peramalan Jumlah Produksi Ikan dengan Menggunakan Backpropagation Neural Network (Studi Kasus: UPTD Pelabuhan Perikanan Banjarmasin," JURNAL TEKNIK ITS, vol. 6, no. 1, pp. 142-148, 2017.

[18] E. Siregar, H. Mawengkang, E. B. Nababan, and A. Wanto, "Analysis of Backpropagation Method with Sigmoid Bipolar and Linear Function in Prediction of Population Growth," Journal of Physics: Conference Series, vol. 1255, pp. 1-6, 2019.

[19] J. Han, Data Mining: Concepts and Techniques (The Morgan Kaufmann Series in Data Management Systems). 2011. 